\title{
Impacts of Border in Borderland Conflict along the Ethio-Sudan Border: Evidence from Metema Woreda, North-Western Ethiopia
}

\author{
Temesgen Eyilet'; Getachew Senishaw ${ }^{2}$ \\ ${ }^{1}$ Lecturer in Sociology, Assosa University, Ethiopia; \\ ${ }^{2}$ Department of Social Anthropology, Addis Ababa University, Ethiopia \\ Corresponding Author: temesgen21eyilet@gmail.com
}

\begin{abstract}
The aim of the study is to understand the dynamics of borderland conflicts in one location -Gonder, north-west Ethiopia, specifically, Metema Woreda - which lies along the Ethiopia-Sudan border. The study employed qualitative research methods such as semi-structured interviews, focus group discussions, case studies, and non-participant observation. The colonial origin of the Ethio-Sudan border is the overall background to the confrontation between farmers and investors over the contested lands in the region. The continued uncertainty over the precise location of the border has aggravated conflict that has yet to be resolved.
\end{abstract}

Keywords: Borderland; land conflict; border perception; Metema Woreda

\section{INTRODUCTION}

In Africa, a large majority of the population rely on agriculture in which access to land is vital to livelihoods (Anseeuw and Alden, 2010; Ansoms and Claessens, 2011). Land in Africa is a valuable and often contested resource; it is a central element in the varied and complex social relations of production and reproduction in which conflict often arises (United States Agency for International Development [USAID], 2005). Competing claims to land and natural resources as well as inequitable and inadequate access to land for the poor has been, and continues to be a source of conflict between various groups in a number of African societies (Derzwan, 2011). In border areas, armed conflicts are not uncommon between communities (Alao, 2007). International borders in Africa were demarcated by and for the interests of the various colonial powers (Okumu, 2010).

Colonial borders are therefore the ultimate background to the contradictory claims over the resources in border areas (AUBP, 2014). This happens particularly, when certain borders consist of distinct populations and lack of agreed demarcation as between Morocco and Algeria, and Ethiopia and Somalia or where the demarcating landmarks, such as rivers, have shifted over time, as between Zambia and Zaire (Ramsbotham and Zartma, 2011). In the case of Ethiopia and Sudan, their border was delimited single-handedly by the British political commissioner. This demarcation remains the cause of periodic tensions between Sudan and Ethiopia (Baharu, 1990; Teshome, 2009).

Rural cross-border land conflicts have a long history in Africa, but have not been given the scholarly attention they deserve. At present, most of such conflicts go overlooked and unreported unless large-scale killing takes place or the state military forces intervene (Bujra, 2002). Meala (2011) studied the eruption of conflict in the late 1990's along the Ethio-Eritrea border but her focus was at inter-state level territorial cross border conflict. Asebe (2016) studied cross border inter-group 
conflicts along the Ethio-Kenya border focusing on the political actors who mobilized people so as to change peoples' perceptions of each other's identities, resource availability, ownership, utilization right and governance. Tesfaye (2017) studied cross border inter-group conflicts along the Ethio - Kenya border, looking at the dynamics of inter-communal conflicts in Moyale, and Cascao (2013) studied cross border land and water resources conflicts in Gambella due to the immigration of people from South. Tasew (2017) conducted a study in the EthioSouth Sudan border looking at how state intervention weakened local systems of conflict resolution. The aforementioned studies were done on borderland areas where similar ethnic groups existed on both sides of the border. Therefore, the roles of contested international borders in cross border land based conflict in distinct borderland communities remains unexamined, and is part of the rationale for this study.

The main aim of this study is to explore the role of the Ethiopia-Sudan border in cross borderland conflict at borderland level. The study further aims to: (a) to understand the perceptions of Ethio-Sudan borderland people towards the international border between the two countries, (b) to investigate the nature and impact of the Ethio-Sudan border in cross border land conflict in the area, and (c) to understand the competing narratives held by both groups of borderland people and to shed some light on the significance of these narratives in the study area. The study attempted to answer the following questions:

- How the Ethio-Sudan borderland community perceives the international border that demarcates the two countries and how community perception of the border differs from the state's conception of the boundary?

- What does the Ethio-Sudan border look like?

- What are the conflicting claims narrated by both borderland communities?

- How the competing claims contribute to cross borderland conflict in the area?

\section{RESEARCH METHODOLOGY AND SETTINGS}

\section{Research Methodology}

Khotari (2004) argues that a qualitative approach to research is vital for subjective assessment of attitudes, opinions and behaviors of the people concerning a particular issue under study. Furthermore, as Vanderstoep and Johnston (2009) note that when the research aim is more of narrative understanding, a qualitative strategy is preferable since it provides a richer and more indepth understanding of the issue under investigation. Furthermore, Marvasti (2004) argues that qualitative research provides detailed description and analysis of the quality, or the substance, of the human experience in any particular situation.

As the aim of this study was to understand the perceptions and opinions of people towards the border, the qualitative method was essential in establishing rapport with informants in a natural setting. At the same time, it gave informants an opportunity to express their ideas in their own words. In line with this, Dawson (2002) states that qualitative research methods are crucial in the study of the attitudes, behaviors and experiences of research participants. The study was based on five months of fieldwork that extended from January, 2018 to May, 2018. During the fieldwork four data collection instruments: in-depth interview, focus group discussions (FGD), case studies and observation were employed.

Semi-structured interview offers an opportunity to develop a conversation along one or more lines without most of the usual chatter that accompanies such engagements. At the same time, through the use of open-ended questions, the interviewee is given the chance to shape his or her own responses or even to change the direction of the interview altogether (Fife, 2005). Therefore, taking in to account such advantages, semi-structured interview were conducted with Ethiopian borderland officials, farmers, investors as well as farm workers. Official informants were selected using purposive sampling while other informants such as farmers, workers and investors were selected based on a snowball sampling technique. The final numbers of each category of informants were determined based on the saturation of data. As Bloor and Wood (2006) and Vanderstoep and Johnston (2009) state, the size of a qualitative sample is considered as sufficient when the criterion of redundancy is met and this is done when an additional informant does not significantly add new information and understanding.

FGD helps researchers to develop understanding of why people think the way they do, members of FGD can reflect new ideas, and the responses of each discussant can be challenged by other participants (Bryman, 2004). The total numbers of FGDs were determined based on the research purpose and time available. Thus, three FGDs were conducted. Through the FGDs, data was collected on the border lander's perception of the border, the impact of the contested border in the cross borderland conflict and competing claims concerning the precise location of the Ethio-Sudan border and its contribution 
to the land based conflict. Kothari (2004) and Payne and Payne(2004) state that the case study is useful to intensive investigation of a particular unit under consideration and its main aim is to identify the factors that account for the behavior patterns of the given unit as an integrated totality. Thus, to supplement the data obtained through the aforementioned instruments, two case studies were undertaken to assess the impact of the contested EthiopiaSudan colonial border in cross borderland based conflict.

The study also employed non-participant observation to look at the nature of border between Ethiopia and Sudan in Metema Woreda (an administrative structure below the zone and above the kebele equivalent to a district). In this regard, Khotari (2004) argued, observation is a scientific tool and a basic method of data collection for the researcher.

The data were analyzed thematically in a coherent manner. As Ezzy (2002) states, thematic analysis involves identifying themes within the data and the categories into which themes will be sorted transcribed and logically interpreted. Brewer (2000) further argues that thematic analysis involves the process of bringing order to the data.

\section{Study area context}

The study was conducted along the Ethio-Sudan border, in Metema Woreda. Metema Woreda, is located about 900 kilometers northwest of Addis Ababa and 188 kilometers west of Gondar town. It is found north of Quara and Alefa, west of Chilga town, south of Tach Armaciho woreda and east of Sudan. The woreda has an international boundary of sixty-five kilometers distance with the Sudan (IPMS, 2005). It is one of the eighteen woredas ' in north Gondar administrative zone of Amhara National Regional State and it is the largest woreda in the zone. According to Metema Woreda Finance and Economic Development Office, the total population of Metema Woreda in 2018, was 127,751 of which 67,153 were males and 60,598 were females. Of the total population of the Woreda, 19,013 (14.9\%) were urban dwellers; while 108,738 (85.1\%) were rural dwellers. The data shows that the majority of the population reside in the countryside of the Woreda.

The major economic activity in the Woreda is mixed farming, (a combination of crop production and livestock rearing). Because of its proximity to Sudan, some members of the local community engage in illegal activities to subsidize their livelihoods. However, crop production is the main livelihood activity for most people living in the area (Kassahun, 2014). Commonly produced crops are: cotton, sesame, sorghum, rice, and mung bean (IPMS, 2005). Among these crops, sesame, cotton, and sorghum are the most important marketable commodities that account for the cultivation of ninety percent of the woreda farmland area (Aysheshm, 2007; Desalegn, 2009). According to Kassahun (2014), there are investors who are engaged in the agricultural sector in the Woreda. Therefore, land is a major means of livelihoods and a highly valued resource in the area.

\section{DATA PRESENTATION AND INTERPRETATION}

\section{State conception of the border}

The state views the border as a means of political representation and of ensuring national identity. It is thought that borders are a means of advancing state political interests through different mechanisms such as custom duty collection, defense construction, army careers and so forth. Therefore, the focus is on the physical (territorial) border. In contrast, the community view of the border is more socially and culturally constructed and most of the time contrary to the demarcations of the state. The basic local conception of the border is dynamic depending on variable opportunities. When there are structural problems posed by the border, the local community's view of the border shifts to the state's definition of the border.

\section{Borderland Community's Perception of the Border}

According to informants, during times of peace, people living along and across the border view the border as an opportunity that enables them to sustain their livelihoods. Hence, most of the time, they do not think of the presence of the border. Along the remote border areas, many people whether farmers or others engage in clandestine economic activities that take advantage of the uncertain delimitation of the border. Certain borderland farmers who have farmland along the border, particularly in the northern part of the border, actively engage in illicit trade using their farming activities as a cover. At the time of crop harvest, farmers buy abundant crops such as maize from the Sudanese at a cheaper price and sell it in Metema Yohannes town with profit by claiming it as their own product. People living along the more remote border area sell some animals and crops from Ethiopia, such as oxen and teff (Ergatosistef), to Sudan. Besides contraband trade, people are also trafficked into Sudan. Concerning perceptions of the border, an informant describes his thought about the economic role of the border in the following way: 
I perceive the border as it offer advantages. I do not think of the existence of the border every day. I have worked on informal oxen trade with Sudanese along the border. But in 2013, when I and my friends were walking with our eight oxen to sell to one Sudanese, the Ethiopian military force caught us and took away our oxen but we escaped. After that time, I lost hope and stopped the work but there are many farmers who run such business till today (Interview with Seyum Aseres: Metema town, 17-08-2017).

At the border, people from Metema town regularly move in to Galabat town to look for a job, to buy clothes, perfume and sugar, or for entertainment. Concerning how the town offers opportunities, a Metema town dweller expressed his view in the following way.

Metema Yohannes and Gellabat towns are twin towns belong to Ethiopian and Sudanese respectively. I always move to Gellabat town for different purpose either to buy relatively cheaper products and to work as a daily laborer since job opportunities are more available. But also I usually go to the town being with my friends to drink Avocado juice. Ialso go there to play with my Sudanese friends since all we can speak both Arabic and Amharic. I consider Metema and Gellabat town as neighboring sisters (Interview with Meketaw Tilahun: Metema town, 22-082017).

According to informants, Metema town is a small border town but contains numerous night clubs. This is due to the relative prosperity arising from the large fertile cash crop lands surrounding the town. Besides, the town is a transit town for human trafficking to Khartoum, capital of Sudan. Therefore, the town is a magnet for investors, large numbers of farm laborers, brokers, migrants and traders. Apart from this, the town is the most convenient point for routine interaction with the Sudanese borderland community. Generally, Metema is a meeting place for diverse groups of people that create a fertile ground for night clubs and the sex trade. With regard to commercial sex work in Metema, a Metema town resident argues that

There are more than two hundred night clubs and private houses that render sexual service. Most of the time, the Sudanese are expected to buy the service during the day time and the locals at night. But illicitly, the Sudanese buy the service at the night time too. On average the Sudanese have to pay between 800-1000 Ethiopian birr for the service but the payment for the locals reduces by half. However, the price of the service may goes up or down depending on the market demand (Interview with Abebe Tariku: Metema town, 1207-2018).

According to informants, the borderis conducive to commercial sex work in Metema Yohannes town. As the Sudanese are charged more for these services than locals, they are one of the main sources of income for night clubs and sex workers.According to state regulations, the border closes at 5:30 pm every day and citizens of each country must return to their country before the aforementioned time. However, occasionally the Sudanese covertly stay in Metema to gain access to sexual services. In this case, they have to pay between eight hundred and one thousand Ethiopian birr. This price is twice that paid by locals because the Sudanese are foreigners. Because of such opportunities, night club owners and commercial sex workers perceive the border as an opportunity.

According to the 2007 census report, in the town these are the most common ethnic groups: the Amhara (78.87\%), the Qemant (10.27\%), the Tigrayan (7.01\%), the Gumuz (2.1\%), and Agaw Awi (1.25\%); all other ethnic groups make up $0.5 \%$ of the population. Of these, the Amhara ethnic group is the dominant one. According to informants, the conception of the border by borderland community is dynamic following the opportunities and challenges posed by the border. According to informants who have been the victims of farmland conflict, the border is a threat to their life and their livelihoods. The border, according to them, is an obstacle to farming on their own farmland due to competing land claims by the Sudanese. Therefore, they describe the border as a peril and have rigid views of it. Regarding this case, one farmer informant said:

I have officially recognized farmland land by the Ethiopian government in a place called Forgena, one of the contested areas along the Ethio -Sudan border. However, a Sudanese investor named Ahmed Abdela claim that the land is his own and there had been occasional fighting with the farmer. Having such disagreement on November 26, 2017, his ordered soldiers forcefully took away his eighty sacks of Sesame from his land. Therefore, I want the border to be rigid and with strict line of demarcation (Getasew Tigabu, 15-08-2017).

Without denying certain benefits, Orthodox religious leaders perceive the border as a threat to the 
socio-cultural values of followers of the Ethiopian Orthodox Church in the area. Because of transborder movements, Ethiopian Christians marry and have sexual relations with Muslim Sudanese. This, according to religious fathers in the church, downgrades the Ethiopian Orthodox religion and the culture of the people on the Ethiopian side of the border. In Metema town, there are two Orthodox Churches such as Church of Yohannes and St. George Church, and surrounding the town are other Orthodox Christian Churches and Orthodox Christianity remains the dominant religion in town. As the religious doctrine prohibits inter-religious marriage and sexual relationships, religious fathers view the border as a menace to orthodox Christianity.

When border conflicts arise in the area, those who view the border as an advantage see it as a barrier for the socio-economic interactions and a threat to their livelihoods. For instance, in 1996, because of cross border land conflict in Delelo farmland, residents of Metema Yohannes town were forced to move back to the town center. The conflicts that occur sometimes create hostility that results in an "us" and the "them" division. Perceptions of the border are dependent upon the stability of the border, the benefit or harm it poses to local populations and the religious ideology of actors. Generally speaking, the locals' conception of the border is flexible and situational.

\section{The nature and role of Ethio-Sudan border in land conflict}

According to Leonardi and Santschi (2016), nondemarcated international borders have been a source of tension, contestation and competition in the border region of various countries. According to the same view, the lack of a clearly demarcated international border between Ethiopia and Sudan accepted by both sides has been a source of cross border tension and conflict. The existing contested border was drawn up when Sudan was under British rule in the 1900s without the participation of Ethiopian representatives. In line with this, Teshome (2009) and Johnson (2010) state that Charles Gwynn, a British royal engineer single-handedly surveyed and demarcated the Ethiopia-Sudan border without the participation of the Ethiopian government. Up to present, the border is the cause of periodic tension between Sudan and Ethiopia borderland people.

The Ethio-Sudan colonial border, which is known as Gwyn's line, after the British engineer who demarcated the border, is not clear since it mainly relies on natural land marks such as mountain, trees and rivers. Through time, the land features have changed or rivers have shifted their direction and created confusion. In line with this, Okomu (2010) states that in eastern Africa, colonial borders were mainly based on natural features which were preferred simply because they required fewer boundary pillars and made the work of the commission easier and speedier. Along the Ethiopia-Sudan border in areas north of Metema Yohannes town River Gwang is considered to be an accepted international border demarcation; in Metema Yohannes town the border is assumed to be Amira River and the bridge over it. This bridge is the only official border in which the two countries' customs and revenue office existed. The Ethiopian borderland residents in Metema Yohannes town accept Amira River and the bridge as the border. The reason is that Metema Yohannes and Galabat towns are linked by common economic interests. Each town's residents benefit from one another. Hence, they consider the two towns as commonly owned. Along the southern part of Metema Yohannes town, mountains and trees have been used to mark the border. However it is difficult to look at clear and consistent border markers.

Figure 1. Gwang River, onepart of a border contested by Ethiopia and Sudan

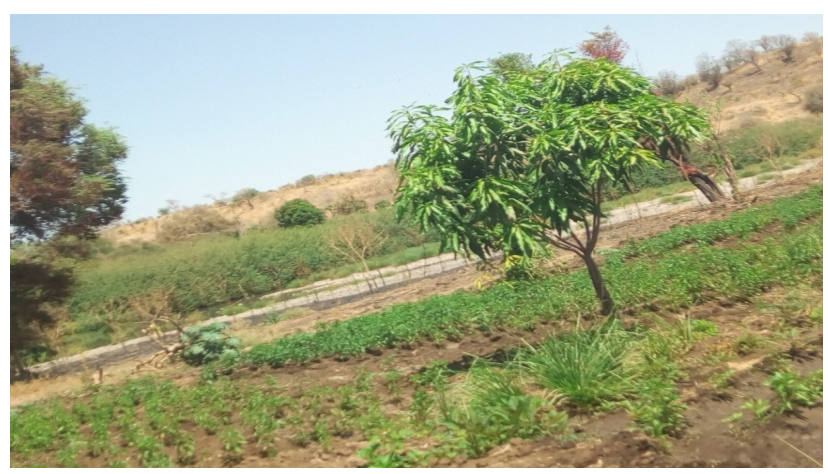

Source: author's photograph, March10, 2018

The Ethiopian-Sudanese borderland is located roughly where the clay plains meet the foothills of the Ethiopian escarpment (Johnson, 2010). An informant, Alemu Zewdu argued "when we see a mountain we claim it as Ethiopian land and when the Sudanese see a flat land they claim it as their own." As such, in some borderland areas showing a mixture of both geographical features such as Merbya, Delelo, Forgena, Mendoka and Dilber farmland areas there is confusion of land ownership. These farmlands are simultaneously claimed by both Sudanese and Ethiopians.

According to Ethiopian borderland farmers, 
contestation over land is a source of conflict between Ethiopian and Sudanese borderland farmers. Lands claimed by Ethiopians in one farming season might be claimed and farmed by Sudanese during another season. In this situation, "farmlands which was cultivated or used by the Sudanese farmers in one farming season might be cultivated by an Ethiopian farmers in another farming season without any kind of peaceful contract between them" (Interview with Sisay Zegeye: Metema town, 1608-2018).

Historically, the border of Ethiopia and Sudan came in to being during the early $20^{\text {th }} \mathrm{C}$. Wondwosen (2009) indicates that until Charles Gwynn came to the border area, the boundary between Sudan (then under Britain) and independent Ethiopia was neither delimited nor demarcated. Though there had been efforts, the Ethiopia-Sudan border was not determined until 1902. During the reign of Emperor Menelik, the British reconquered Sudan by defeating the Dervishes (Mahdists) of Sudan in 1897, and covertly demarcated the EthioSudan border in order to gain strategic control over the Ethiopia-Sudan borderland region.

Ethiopia's borderland spokespersons argue that the Sudanese farmers or investors used the colonial border's geographical positioning system (GPS) as a standard to determine their land but this method has not been accepted by Ethiopian borderland farmers or investors. In relation to this, Gwyn (1937) noted the failure of the Abyssinian government to send trained and educated personnel to represent the Ethiopian side. Furthermore, the unwillingness of the Ethiopian government to employ Europeans to represent Ethiopia in the demarcation process is part of the problem of the Ethiopia-Sudan border demarcation issue. As Ethiopian borderland people rationalize, the colonial border demarcation was done by colonial officials to advance their interests without considering the needs of local people. The Ethio-Sudan colonial border demarcation is "like stealing cow or oxen from someone" (Interview with Getahun Zegeye: Metema town, 16-08-2018). Likewise, Okomu (2009) states that with regard to the colonial border demarcation it remains apparent that wherever colonial political interests were seen as paramount, local interests were totally overlooked.

According to informants, Ethiopia and Sudan entered into border demarcation negotiations in 2008. However, before this, no efforts were made to consult local borderland people. The demarcation process consisted of technical experts and representatives from the governments of both countries. Nevertheless, the demarcation process failed mainly due to the neglect of local stakeholder's and people's resistance against the demarcation process. In line with this, the African Union Border Programme (AUBP, 2014) states that undertaking a programme to sensitize the local population is one of the important phases of border demarcation; however, colonial borders were drawn without such programs and today, it is a cause of conflict between surrounding dwellers of the borderlands since they advance contradictory claims over the borderland resources.

\section{Competing claims about the precise location of the Ethio-Sudan border}

\section{The claim of Ethiopian borderland Community}

Incompatible claims about border line demarcations lead to cross border contestation over territories (Leonardi and Santschi, 2016). Related to this view, residents of Metema Yohannes town claim the location of the EthioSudan border to be in "Medene", which is located 150 kilometers away from Gedaref, a state in the eastern part of Sudan. As evidence, informants cited the existence of a man-made stone tablet from the time of emperor Menilik II in the early 1900's. They claim that the tablet is inscribed in Ge'ez (Ethiopian Orthodox Church language) and in English. Because of this, people perceive the tablet as providing a marker for the exact historical location of the border. Additionally, informants argue that very old Christian churches exist in Medene and Tiya, towns located in the eastern part of Sudan and the southern end of Metema Yohannes town. Hence, they claim these places as Ethiopian lands.

Informants further argued that during the reign of Emperor Haile Selassie I (1930-1974) the historical EthioSudan border in the southern part of Metema Yohannes town had been Basonda. It lies 40 kilometers inside Sudan from the present contested border. In this regard, a farmer informant, Lingerh Tadesse argued "I clearly know the custom point in Basona during the time of Emperor Haile Selassie. However, at the present it is Sudanese town. Also, on the way to Metema, Kunina, 20 kilometers from Metema Yohannes town have been historically the border between the two countries." However, though informants could not give the exact time when the border shifted, they claimed the Sudanese expanded into Ethiopia in the $19^{\text {th }}$ and $20^{\text {th }}$ centuries when Ethiopia's political situation was unstable.

Contrary to the arguments of non-official informants, official informants argued that it was Ethiopians who were occupying Sudanese land. According to these informants, if the colonial border is considered, many Ethiopian farmers would be displaced. Relying on contradictory ideas of official and non-official 
informants, it is possible to conclude that the difference in their outlook stems from their respective political views.

Figure 2. Amira River Bridge, the Border of Metema Yohannes - Galabat towns

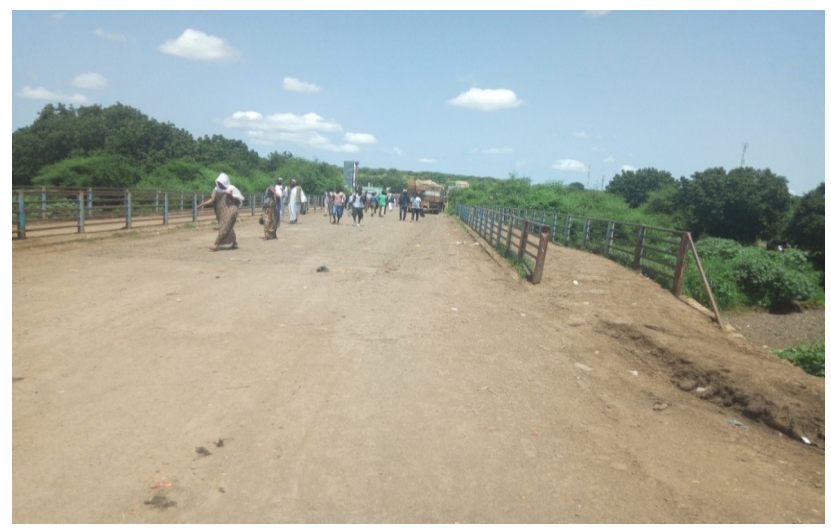

Source: author's photograph taken on April 16, 2018

\section{The Borderland Sudanese claim}

In contrast to the views of the Ethiopians, the Sudanese claim all plain lands in the area as their own. Their phrase "Alfi Sjera Laloo Huwa Aradina, implies all Laloo grown lands are part of the Sudan. This area includes places up to Negade Baher, a town, 87 kilometers far from Metema Yohannes town. The Sudanese claim that the Laloo tree, which is common in Sudan, does not exist in any part of Ethiopia. According to Ethiopian farmer informants, due to the fear of Sudanese claim, once in the early 2000s, Ethiopian borderland people were discreetly encouraged to cut Laloo trees and thus many Laloo trees were cleared in the Ethiopian borderland region. Consequently, Sudanese blame Ethiopian farmers for expanding outwards to Sudanese areas which cased frequent conflict over land.

Another Sudanese claim is founded on the former name of the present-day site of Gende Wuha, which is the administrative seat of Metema Woreda. Formerly, Gende Wuha was known by the name Shedi from 1977 up to 2004. Later in 2004 it got its current name Gende Wuha. For this reason, Sudanese claim the name Shedi, is an Arabic word, which indicates its Sudanese founder. It is further assumed by Sudanese that the name change was due to fear of Sudanese claims of ownership rights.

The theory of territorial identity assumes that territorial specification of group membership produces a sense of homeland and that this feeling creates conflict (Kolssov, 2005). In line with the argument of the theory, the historical claims about the border and land ownership create the feeling of territorial identity and conflict. The
Sudanese give special value to their land; they view it as their child. So, they are concerned to keep it from any encroachment by others. Similarly, Ethiopian borderland people also have strong emotional attachments to the land that they assume is theirs. They claimed that the territory, which had been under Ethiopian control for many years in the past, was taken by the Sudanese under the current regime. In support of this claim is the handing over of a sizeable plot of Ethiopian agricultural to Sudanese investors at Delelo borderland area.

Figure 3. Laloo Trees

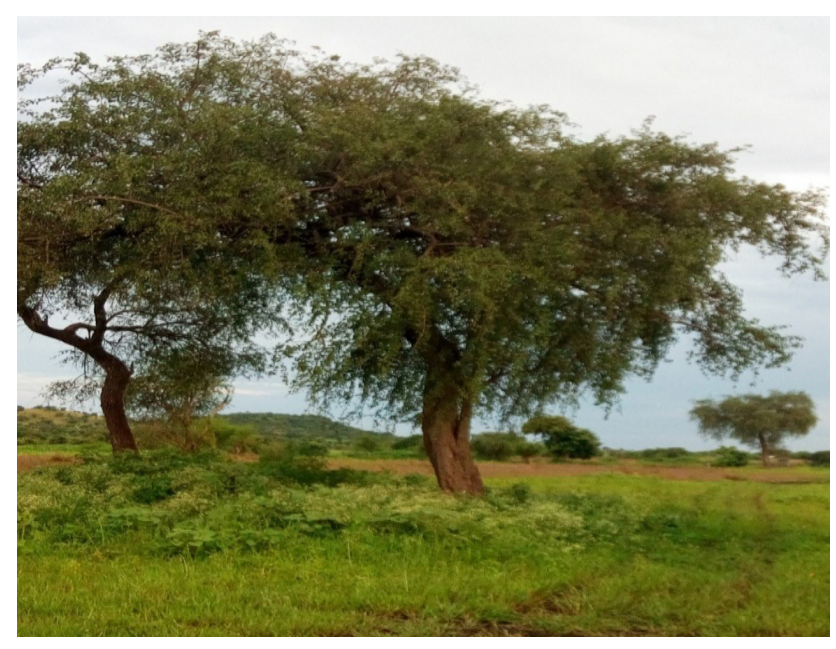

Source: author's photograph taken on April 19, 2017

According to informants, conflicts that arise from a sense of territorial ownership, involve not only farmers who have issues over a particular farm, but it is also the concern of borderland people, who have comparable intentions to confiscate land through confrontation with the Sudanese irrespective of their economic activity. Therefore, cross border conflicts that arise from the feeling of "our land" are common along the EthioSudan border regions. The following case strengthens the above statements on how inter-group conflicts arise from competing claims of land ownership.

Once in June 2014, a place called Nefs Gebiya, along the Ethio-Sudan border was occupied by the Sudan military force. At that time many farmers and other dwellers asked Metema Woreda concerning officials to provide them military support but the officials refused by saying it would be resolved through diplomacy. Many border land people had gone to expel the Sudanese alone and later people told officials "you have already left it for the sake of your position; it is okay not to support 
us. We can fight them only for thirty minutes and if we cannot win within this time, you will help us thereafter". Then shortly farmers went for confrontation but security officials followed them and were able to return these farmers. The case was resolved through diplomacy. Latter, Sudanese military force occupied the same place on July 3, 2018 and farmers and other people in Metema Woreda face off the Sudanese military force and were able to expel them from the area (interview with Abebe Tamiru: Metema town, 27-02-2018).

This case shows that borderland people's feeling of territorial ownership is the reason behind inter group cross border conflict. Farmers' involvement in such kinds of conflict emanates from the sense of territorial identity, which is the feeling of 'our' land. Therefore, from such data, one can argue that the cause of the Ethio-Sudan cross border conflicts goes beyond economic factors.

According to informants even if the intensity of the conflict seems low at the moment, it could intensify in the future since the Ethiopian borderland people are beleaguered by a persistent sense of territorial encroachment. Whenever viable conditions are created such as internal political instability, or political power transition, the two sides try to seize the disputed land. Conflicts that arise from the feeling of territorial ownership are occasional, group based and deadly as compared to the common inter personal cross border conflicts that arise from farmland demand. It is deadly since it is organized and involves many actors.

According to informants, it was not always borderland farmers and investors who were the key actors in such kinds of conflict. Political actors were also part of the group based cross border conflict along the EthioSudan border area. Regarding this, an investor informant argued:

On July 3, 2018, the Sudanese soldiers confront Ethiopian investors and farmers in Delelo. It was a new kind of cross border conflict. I have never seen when the Sudanese use such kind of attacking strategy. Before this time, when they pop to the South direction, they curve around their face in to the north. But now with the support of Tigray People Liberation Front, they did front view kind of fighting (Interview with Seyum Bisewur: Metema Town, 10-03-2018).

It is possible to conclude from the above explanation that the support given by the TPLF to Sudan military forces may be due to grievances associated with the loss of political power in Ethiopia at the time. TPLF fighters also had used the Ethio-Sudan border during the time of their fighting with the Ethiopian military government for sixteen years before they came to power. Hence, they had strong networks with borderland Sudanese.

All in all, the issue of territorial ownership entails that cross border conflicts along the Ethio- Sudan border regions do not exclusively emanate from demand of land for production. The conflict is also associated with deeply held sentiments of territorial ownership of homelands.

\section{CONCLUSION}

The main factor underlying the Ethio-Sudan cross borderland conflict is the contested nature of the border that demarcates the two countries. At borderland level, Ethiopia and Sudan have no definite mutually acceptable borders since the assumed border has colonial roots and has unclear natural feature markers. Hence, it gives rise to irreconcilable claims between the two groups of border landers. Beyond this, both borderland peoples make contradictory claims about the precise location of the Ethiopia-Sudan border in Metema Woreda. Border land is symbolic in the minds of borderland people on both sides. This perception and unclear physical boundaries have created competing land ownership claims and conflict among the borderland people. As the Ethiopia-Sudan border area in Metema is a dynamic site of agricultural investment and farming, the border plays a significant role in land-based conflicts. Until there is effective mediation, the disputed border will continue to be a source of intermittent conflict as people on either side continue to pursue their livelihood and national identity interests.

\section{REFERENCES}

Africa Union Border Programme (2014). Delimitation and Demarcation of Boundaries in Africa: The User's Guide ( $2^{\text {nd }}$ ed.). Ethiopia: African Union Commission.

Alao, W. (2007). Natural Resources and Conflict in Africa:

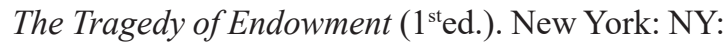
University of Rochester Press.

Anseeuw, W. and Alden, C. (eds.) (2010). The Struggle Over Land in Africa: Conflicts, Politics and Change ( $1^{\text {st }}$ ed.). South Africa: Human Sciences Research Council Press.

Ansoms, A and Claessens, K. (2011). Land Relations and Local Livelihoods in the Great Lakes Region. In Ansoms and Marysse (eds.). Natural Resources and Local Livelihoods .UK: Palgrave Macmillan, pp.3-22.

Asebe, R. (2016). Competing Orders and Conflicts at the 
Margins of the State: Inter-Group Conflicts along the Ethiopia-Kenya Border. African Journal of Conflict Resolution, 16(2), 57-83.

Bloor, M. and Wood, F. (2006). Key Words in Qualitative Methods ( $1^{\text {st }}$ ed.). A Vocabulary of Research Concepts. Great Britain: Cromwell Press.

Brewer, J. (2000). Ethnography. Buckingham: Open University Press.

Bryman, A. (2004). Social Research Methods. Oxford: Oxford University Press.

Bujra, A. (2002). African Conflicts: Their Causes and Their Political and Social Environment. Ethiopia: Development Policy Management Forum.

Cascao, A. (2013). Resource-based Conflict in South Sudan and Gambella (Ethiopia): When Water, Land and Oil Mix with Politics. Retrieved from https://www. researchgate.net/publication/314453096, accessed on November 22, 2017.

Dawson, C. (2002). Practical Research Methods: A UserFriendly Guide to Mastering Research Techniques and Projects. United Kingdom: How to Books Ltd.

Derzwan, J. (2011). Conflict SensitiveLand Policy and Governance in Africa. Retrieved from http:// www.international-alert.org/publications/conflictsensitive-land-policy-and-land-governance-Africa, accessed on July 3, 2017.

Desalegn, M. (2008). Social Networks and Diffusion of Agricultural Technology: The Case of Sorghum in Metema Woreda, North Gondar, Ethiopia. MSc thesis, Haramaya University, Ethiopia.

Ezzy, D. (2002). Qualitative Analysis: Practice and Innovation. Australia: Allen \&Unwin

Fife, W. (2005). Doing Field Work: Ethnographic Methods for Research in Developing Countries and Beyond. New York, NY: Palgrave Macmillan Press.

Johnson, D. (2010). When Boundaries Become Borders: The Impact of Boundary Making in Southern Sudan's Frontier Zones. Contested Borderlands. United Kingdom: Rift Valley Institute.

Kassahun, G. (2014). The Role of Small Towns for Surrounding Rural Development: The Case of Metema Town, North West Ethiopia. Open Access Library Journal. http://dx.doi.org/10.4236/ oalib.1100930, accessed on December 182017.
Khotari, C. (2004). Research Methodology, Methods and Techniques (Rev.ed.). India: New Age International. Kolossov,V. (2005). Border Studies: Changing Perspectives and Theoretical Approaches. Geopolitics, 10(2), 606-632, DOI: 10.1080/14650040500318415.

Leonardi,C. and Santschi, M. (2016). Dividing Communities in South Sudan and Northern Uganda: Boundary Disputes and Land Governance. London: Rift Valley Institute.

Marvasti, A. (2004). Qualitative Research in Sociology: An Introduction ( $1^{\text {st }}$ ed.). London: Sage publication.

Meala,T. (2011). The Causes of Return to Conflict and the Geopolitical Dynamics in the Horn of Africa: The Eritrean-Ethiopian Border Conflict. Unpublished Master's Thesis, University of London, England

Okumu,W. (2010). Resource and Border Disputes in Eastern Africa. Journal of East African Studies, 4(2), 279 $-297$.

Payne, G. and Payne, J. (2004). Key Concepts in Social Research. London: Sage publications.

Ramsbotham, A., and Zartman, W. (2011). An International Review of Peace Initiatives: Building Peace Across Borders. United Kingdom: Conciliation Resources Press.

Tasew, G. (2017). Cross-Border Intergroup Conflicts in the Horn of Africa: A Case Study of Ethiopia-South Sudan Borderland People. https://www. wilsoncenter. org/article/ethiopia- south-sudan-cross-borderconflicts, accessed on May 19, 2018.

Tesfaye, M. (2017). Borderland Communities in the Horn: Avoiding Assumptions and Learning from History. Horn of Africa Bulletin, 29(3), 5-19.

Teshome, T. (2009). Characteristics of Property Units in Ethiopia, the Case of Two Pilot Projects in Amhara National Regional State. Nordic Journal of Surveying and Real Estate Research, 6(2), 7-24.

USAID (2005). Toolkit on Land and Violent Conflict. Retrieved from http:/www.usaid.gov/our_work/ crosscuttingprograms/conflict/publications/toolkits. html, accessed on August 2, 2017.

Vanderstoep, S and Johnston, D. (2009). Research Methods for Everyday Life: Blending Qualitative and Quantitative Approaches (1 ${ }^{\text {st }} \mathrm{ed}$.). San Francisco, CA: Jossey Bass. 